\title{
Magna Carta clauses 4 and 5 and the origins of accountability
}

\author{
Joshua Getzler
}

\section{Public AND PRIVATE dUe PRocess ANd Magna CARTA}

The common law defies periodization. Our modern law was formed in the wake of the Common Law Procedure Acts 1852-60 and the Judicature Acts 1873-75, but we can hardly work within the common law without constant glances back to earlier periods that deployed very different actions, procedures, and organizing doctrines. Indeed, judges to this day can still cite ancient doctrine as if the ideas of lawyers of distant times have an entirely live presence in their own later debates. With such constant intellectual time travel, the past of our law is not even past. ${ }^{1}$

Magna Carta is the ne plus ultra of such juristic timelessness. It is mainly in the arena of constitutional law that the 1215 statute has operated as a live authority to be cited in court; ${ }^{2}$ but Magna Carta also has an interesting post-history as a progenitor of fiduciary principles in private law. Magna Carta gave the first legislative restatement of the nascent legal controls of stewardship by guardians and bailiffs, which led in turn to the evolution of modern doctrines for the control of accountable parties such as agents, bailees, executors, guardians, trustees, and directors. By reviewing the operation of Magna Carta in this area we may better be able to understand why accountability has mattered across our legal history, and thereby better grasp the problems and uncertainties faced by our law today. At the time of Magna Carta the line between public and private accountability was difficult or impossible to draw within a feudal system merging jurisdictions with estates. ${ }^{3}$ However, continuity across the field or public and private accountability may be found in the idea of due process - that decision-makers

\footnotetext{
${ }^{1}$ See eg Berrisford v Mexfield Housing Co-operative Ltd [2012] 1 AC 955; [2011] UKSC 52, [23]-[44] per Lord Neuberger; J Roche, 'Legal history in court: lessons from Mexfield and Southward' [2016] Conveyancer 286; cf Willers v Joyce [2016] UKSC 43, [182]-[184] per Lord Reed, doubting the utility of historical case-law as authorities or sources for the $21^{\text {st }}$ century. On the diachronic nature of commonlaw reasoning see J Getzler, 'Two Timing the Law' (2015) 163 University of Pennsy/vania Law Review Online 355.

${ }^{2}$ Magna Carta has been cited an average of six or seven times a year in English courts of record since 2013 , with about $75 \%$ being public law decisions concerning liberty of the subject and the legality of government decisions. Australian courts have yielded around twice as many Magna Carta citations per annum in the same period. Citations may have spiked in the 2015-16 as the anniversary year heightened jurists' consciousness of the statute. For a useful survey of historical uses of Magna Carta, see A Arlidge and I Judge, Magna Carta Uncovered (Hart Publishing, Oxford, 2014).

${ }^{3} \mathrm{~F}$ Pollock and FW Maitland, The History of English Law Before the Time of Edward I (2 vols, 1895, 2nd edn, Cambridge University Press, Cambridge, 1898, reprinted 1968) ii, 1-3.
} 
wielding power based on jurisdiction, status, or estate should do so in a manner measurable and controllable by law.

\section{THE MODERN DECLINE OF ACCOUNTABILITY}

Accountability is a strong concept in today's public law, but it is in decline in the private law sphere. The reasons for that decline are complex, and to divine the causes we must start with basics. Accountable parties are those charged with the dynamic management of the assets and affairs of others, and the law must find means to measure misfeasance where the managerial duties are played out across time, perhaps with no single moment of isolated breach causing loss. Our modern courts have lately been converting accountability cases into tort- or contract-like actions sounding in damages for breach of an assumed duty of care, rather than cases for the specific enforcement of due administration and correct performance of an office, mandate, or trust. The tort/contract approach yields a secondary compensation duty to make up for loss caused by breach, which may be subjected to causal apportionments, negotiated exemptions, and the full gamut of general defences including limitation. The accountability approach directly enforces a primary duty to eliminate the breach and vindicate the original managerial duty, whether by an original or substitutive performance of the original duty, or a falsification by rescission of an inconsistent action or transaction; in affording such remedies defences to breach such as causal apportionments or exemptions may be irrelevant.

The new breach-of-duty secondary enforcement model was developed in a series of significant English cases including Bristol Building Society v Mothew, ${ }^{4}$ Armitage v Nurse, ${ }^{5}$ Target Holdings Ltd v Redferns, ${ }^{6}$ and most recently and controversially, in the Supreme Court decision of AIB Group (UK) Ltd v Mark Redler \& Co. ${ }^{7}$ Lord Toulson in the AIB case treated the older account measures of fiduciary control through primary liability as nothing more than 'compensation ... clothed by the court in the literary costume of equitable debt', ${ }^{8}$ adding this abrupt dismissal of the primary enforcement model: 'There is something wrong with a state of the law which makes it necessary to create fairy tales'. ${ }^{9}$ In the $A I B$ case the primary remedy sought was rescission of a plainly wrongful disbursement and restoration of a depleted fund, in a situation where the managing fiduciary had failed to bring a complete substitute

\footnotetext{
${ }^{4}$ [1998] 1 Ch 1.

5 [1998] Ch 24; see also Spread Trustee Co Ltd v Hutcheson [2012] 2 AC 194 (PC).

${ }^{6}$ [1996] 1 AC 421.

${ }^{7}[2015]$ AC 1503.

${ }^{8} \mathrm{Ibid}$, at [61].

${ }^{9} \mathrm{Ibid}$, at [69].
} 
asset back into the fund. ${ }^{10}$ Lord Toulson and the court measured the putative loss caused by the wrongful disbursement by distributing responsibility for the ultimate shortfall between the principal and the solicitor-agent, arguing that tort and contract rules for causally limiting loss should apply to managerial relations involving a time-limited commercial purpose. The fund was not to be reconstituted to its ex ante state prior to the breach of the fiduciary instruction.

$A I B$ accelerated a shift in English law that sidelines accountability as a distinct measure of remedy in private law. This shift has unleashed a torrent of commentary agonizing over where the law is going and whether the judges properly understand the implications of their decisions. ${ }^{11}$ One important mistake is the supposition that accountability is some kind of equitable doctrine associated with the distinct deterrent and prophylactic policies of trusts and fiduciaries, an approach that ought to be eliminated when there is a perceived collision with the imperatives of modern contract or tort policies. But this equitable characterization of accountability mistakes its roots as a general legal control of managerial relations. Legal historians have shown how accountability underpinned and enforced feudal, family, and commercial relations in the ancient common law, centuries before the Court of Chancery developed equitable procedures of account to circumvent the common law's evidential restrictions. ${ }^{12}$ It seems entirely appropriate in the wake of the 2015 anniversary of Magna Carta to investigate the more distant legal origins of accountability doctrine, and to show why such doctrine developed and persisted in both common law and equity across the centuries. Understanding this genesis may help us decide whether accountability as a legal category deserves a continuing place in our law, or should finally receive its quietus, as Lord Toulson seems to advise. The rest of this essay

\footnotetext{
${ }^{10}$ See further J Getzler, “"'As If." Accountability and Counterfactual Trust' (2011) 91 Boston University Law Review 931.

${ }^{11}$ Hall v Libertarian Investments Ltd [2013] HKCFA 93 Lord Millett NPJ; S Degeling and JNE Varuhas, eds, Equitable Compensation and Disgorgement of Profit (Hart Publishing, Oxford, 2017), notably essays by J Edelman, M Conaglen, J Penner, and L Ho; S Gardner, 'The Exodus from Account' (MS, 2016, on file with author); C Mitchell, 'Stewardship of Property and Liability to Account' [2014] Conveyancer 215; JD Heydon, 'Modern Fiduciary Liability: The Sick Man of Equity?' (2014) 20 Trusts \& Trustees 1006; J Getzler, 'Financial Crisis and the Decline of Fiduciary Law', in C Morris and D Vines, eds, Capital Failure: Rebuilding Trust in Financial Services (Oxford University Press, Oxford, 2014) 193208.

${ }^{12}$ Seminal historical analyses of account doctrine showing its early common-law development are provided by EO Belsheim, 'The Old Action of Account' (1932) 45 Harvard Law Review 466; TFT Plucknett, The Medieval Bailiff (Athlone Press, London, 1954); SJ Stoljar, 'The Transformations of Account' (1964) 80 Law Quarterly Review 203; SFC Milsom, 'Account Stated in the Action of Debt' (1966) 82 Law Quarterly Review 534. Important recent contributions include J Watson, The Duty to Account: Development and Principles (Federation Press, Annandale NSW, 2016); A Licht, 'Lord Eldon Redux: Information Asymmetry, the Roots of Accountability, and the Structure of Fiduciary Loyalty' (2017) 27 Oxford Journal of Legal Studies doi.org/10.1093/ojls/gqx003.
} 
will concentrate on the older law, and leave the reader to draw appropriate conclusions regarding present curial policies.

\section{HOLDING THE GUARDIAN TO ACCOUNT: 1215 AND AFTER}

The chief historical doctrines that fall to be examined are waste, account, and disparagement. The doctrines are evoked in chapters 4, 5 and 6 of Magna Carta as ordained by King John in 1215 and reissued by Henry III in 1225 and Edward I in 1297.

4. The guardian of the land of an heir who is thus under age, shall take from the land of the heir nothing but reasonable produce, reasonable customs, and reasonable services, and that without destruction or waste of men or goods; and if we have committed the wardship of the lands of any such minor to the sheriff, or to any other who is responsible to us for its issues, and he has made destruction or waste of what he holds in wardship, we will take of him amends [and recompence therefore (words added in 1297)], and the land shall be committed to two lawful and discreet men of that fee, who shall be responsible for the issues to us or to him to whom we shall assign them; and if we have given or sold the wardship of any such land to anyone and he has therein made destruction or waste, he shall lose that wardship, and it shall be transferred to two lawful and discreet men of that fief, who shall be responsible to us in like manner as aforesaid.

5. The guardian, moreover, so long as he has the wardship of the land, shall keep up the houses, parks, fishponds, stanks, mills, and other things pertaining to the land, out of the issues of the same land; and he shall restore to the heir, when he has come to full age, all his land, stocked with ploughs and wainage, according as the season of husbandry shall require, and the issues of the land can reasonably bear.

6. Heirs shall be married without disparagement, yet so that before the marriage takes place the nearest in blood to that heir shall have notice. ${ }^{13}$

What was the mischief addressed by these clauses? At common law the heir came of age at 21 , and during the minority the infant heir would become a ward under the guardianship of the immediate lord, bestowing both patriarchal control of the person of the infant and seisin of the vacated estate on the lord. The guardian's control was typically used to extract value, including not only take-over of the economic value of the land but also sale of the ward's marriage (which the ward himself could and did pre-empt for a capital sum). The theory of chivalrous guardianship was that the lord had to be compensated properly for his loss of military services and also reimbursed the costs of caring for the infant heir; chivalrous guardianship was only very partially about protecting the infant ward during his vulnerable years. The entire wardship itself could be sold for a capital sum and there was a

\footnotetext{
${ }^{13}$ Magna Carta 1215 (Yale Avalon translation). The 1225 and 1297 reissues of Magna Carta are in similar terms, though the amplifying words in square brackets in c. 4 are added in 1297.
} 
considerable market for such incidents. ${ }^{14}$ Tenants resorted to various devices to evade a wardship, such as sham leases, or chains of subinfeudation granting the land to a sub-tenant in fee for a high capital value and low value service in return, devices that would hollow out the value of the wardship of the tenant's heir to the higher lord. The Crown was in a special position, and could claim guardianship over not only the body and marriage of the heir as ward but the entire estate, provided that the deceased tenant held any one of his tenures ut de corona, directly of the Crown by knight's service or grand serjeanty, a virile claim known as prerogative wardship. ${ }^{15}$ This quality of tenures was to have powerful fiscal effects centuries later, for Henry VII and especially Henry VIII vigorously applied prerogative wardships to the full estates of families who had received grants of land directly from the Crown, notably after the dissolution of the monasteries in the late $1530 \mathrm{~s}^{16}$ Such grants could prove a poisoned chalice for the recipients of royal largesse, for the courts upheld the rule that entire estates fell into wardship if the holder of the estate had any direct tenurial relationship with the Crown. Protection of prerogative wardship is a large cause of the passing of Quia Emptores in 1290 to end subinfeudation and enforce substitution so as to maintain the value of wardships and the other feudal incidents throughout the feudal ladder, but especially for the Crown. Mesne lords might in any case have ambiguous views about the value and burden of wardship: it would be costly and inconvenient should their own heirs end up as wards of the Crown, but on the other hand they might themselves end up as profit-taking guardians of their own tenants' lands, and so would want to have the rights and obligations of feudalism enforced in regularized form. One may read the late Sir James Holt's studies of Magna Carta as placing this ambiguous impulse at the centre of the whole story - how to apply rule-based controls on the Crown and on mesne or lower tenants simultaneously without destabilizing the governmental and social order. ${ }^{17}$

Various legal controls shackled the destructive power of guardians. First are set remedies to restrain the reduction of the value of the managed estate or dishonour of the person of the ward. Magna Carta c. 4 ordains that waste committed by a guardian, or the taking of unreasonable levels of profit from the estate to the reduction of the estate, amounts to an abuse of office that leads to loss of that office and transfer to two fresh guardians. Magna Carta c. 5 requires that the land be restored to the heir at

\footnotetext{
${ }^{14}$ This practice adumbrates the notorious essay by E Landes and RA Posner advocating a market for adoptions, 'The Economics of the Baby Shortage' (1978) 7 Journal of Legal Studies 323, revisited in 'The Regulation of the Market in Adoptions' (1987) 67 Boston University Law Review 59.

${ }^{15}$ Pollock and Maitland, above n 3, i, 318-29.

${ }^{16} \mathrm{HE}$ Bell, An Introduction to the History and Records of the Court of Wards and Liveries (Cambridge University Press, Cambridge, 1953).

${ }^{17} \mathrm{JC}$ Holt, Magna Carta ( $3^{\text {rd }}$ edn, G Garnett and J Hudson, eds, Cambridge University Press, Cambridge, 2015); Colonial England, 1066-1215 (Hambledon Press, London, 1997).
} 
majority with due reinvestment of the capital of the farm, with built capital kept in repair using the profits or issues of the land as is reasonable. Thus c. 4 stints taking out resources from the estate to the diminution of capital; and c. 5 requires adding in of resources or inward investment in order to maintain capital. Magna Carta c. 6 affords a personal protection; it prohibits disparagement of heir or the making of a marriage with a person of inferior rank such as a villein, a maimed person, and perhaps a burgess, to the dishonour of the heir. This prohibition worked against the conversion of higher status into cash, an exploitation and reduction of the ward's person comparable to waste of the estate.

What practical remedies were available to the heir? Displacement of an errant guardian by order of the King has been mentioned. But the Magna Carta text makes no mention of ex ante restraint of guardian actions for example by prohibition; nor is there mention of any remedy of compensatory damages for loss caused to the land, or pecuniary restitution to make up missed or diverted investment of profits. Both prohibition and damages for waste may conceivably be recognized in cases collated in Bracton's Note Book, further mentioned in Bracton's treatise De Legibus, and so dating some ten or so years after Magna Carta:

When a guardian commits waste in his wardship and is convicted thereof, whether it was done before a prohibition or after, he will incur the following penalty, that is, in the first place he will lose the wardship, will remain in the king's mercy, and will restore damages [et damna restaurabit]. And that this is so may be found among the pleas which follow the king in the twenty-second year of his reign, in the county of Huntington [the case] of John Dacus and the daughter and heir of John of Bray, before John de Lacy, earl of Lincoln, and William of Ralegh. ${ }^{18}$

The reference to a mechanism of prohibition involves a writ from the king overlaying the guardian lord's jurisdiction and inserting an instruction on how the jurisdiction or estate is to be wielded, for example initiating a restraint on waste that is already initiated, or perhaps anticipated. Shanks and Milsom in their edition of the Novae Narrationes bring cases indicating that the writ of prohibition did not express or constitute the claim to restrain waste but was only an auxiliary remedy. ${ }^{19}$ The shadowy requirement of a royal prohibitory writ to constitute a claim for waste or mark the inception of an anti-waste duty was finally abolished in 1285 by Statute of Westminster II c. 14:

Whereas for waste done in the inheritance of any person a writ of prohibition of waste has been used to be granted, by which writs many were deceived, thinking that such as had done

\footnotetext{
${ }^{18}$ Henry de Bracton, De Legibus et Consuetudinibus Angliae (4 vols, GE Woodbine (ed), SE Thorne (trans), Belknap Press, Cambridge, Massachusetts, 1968-1977), iii, 411, drawing on Bracton's Note Book, no 1201 \& no 1840 (1227/28).

${ }^{19}$ Novae Narrationes (E Shanks and SFC Milsom (eds), Selden Society vol 80, London, 1963) 15-18, 129-32, 305-10.
} 
the waste should not need to answer but only for waste done after the prohibition to them directed: our Lord King, to remove from henceforth this error, has ordained, that of all manner of waste done to the damage of any person, there shall from henceforth be no writ of prohibition awarded, but a writ of summons, so that he of whom complaint is shall answer for waste done at any time.

This is jurisprudentially interesting because it conceptualizes waste as a harm to the inheritance or reversion, rather than a flouting of tenurial relationships that fall under the supervisory jurisdiction of the Crown.

Milsom in his discussion of the Novae Narrationes surmised that Bracton's reference to direct damages may simply refer, with scant accuracy, to amercements and restitutions of executory issues, and so are not compensatory claims for past losses. If Bracton's reference to damna does suggest direct compensation for the heir, this is best seen as an anomaly. Milsom ${ }^{20}$ reasoned backwards from the 1278 Statute of Gloucester c. 5. That statute affirms waste remedies against life tenants, lessees, and women in dower, and applies treble damages for the past waste as taxed or measured by the court, on top of confiscation of the thing wasted. However, the treble damages rule for executed waste is not applied to military guardians, but rather damages are here only offered as a partial compensation on top of the restoration of issues to the ward:

And for waste made in the time of wardship, it shall be done as is contained in the Great Charter. And where ... he which did waste during the custody, shall lose the wardship, it is agreed that he shall recompense the heir his damages for the waste, if so be that the wardship lost do not amount to the value of the damages before the age of the heir of the same wardship.

This rather complicated damages rule reflects that underlying sense that chivalrous guardianship is fundamentally for the benefit of the guardian, though that benefit will be cancelled if abused. There is also plentiful evidence from the later thirteenth century onwards that possessory assizes were used as a vehicle of enforcement both for against the guardian, this because wrongful sale and assignment away of the estate held in care was often put in issue as a type of expropriation of the heir's expected seisin; the Year Books and extant case law spell out how novel disseisin and mort d'ancestor were bent to this purpose..$^{21}$

\footnotetext{
${ }^{20}$ Milsom, 'Legal Introduction' to Novae Narrationes, above n 19, cxc-cxcviii. The operation of the 1278 statute is further explored through the case law by PA Brand, Kings, Barons and Justices: The Making and Enforcement of Legislation in Thirteenth-Century England(Cambridge University Press, Cambridge, 2003) 345-47.

${ }^{21}$ See Belsheim, above n 12, 476-79; Brand, above n 20, 348-61.
} 


\section{SOCAGE GUARDIANSHIP AND ACCOUNT}

Two generations after Magna Carta, the duties applied to guardians were greatly enlarged by the Provisions of Westminster 1259 and the Statute of Marlborough 1267. One of the chief reforms was to apply extensive accounting duties to guardians of wards in socage tenure. In effect, and to use an anachronistic description, these provisions constituted socage guardians as trustees disabled from taking personal profit. Guardians holding military or chivalrous tenures could still keep the reasonable issues as compensation for the temporary abatement of services from the heir, as under the old law; but guardians were disbarred from the profits of socage tenures, the normal form of holding involving fixed services in return for agricultural land. Even before Magna Carta, socage tenures had attracted a special protection. Glanvill stated a simple rule that a socage wardship should go to the side of the family to which the property could not descend. 'For, by law, wardship of a person never goes to anyone who might be suspected of being able, or of wishing, to claim any right in the inheritance' ${ }^{22}$ It was a very wise prophylactic rule to eliminate incentives that might cloud the motives of supposedly upright guardians and rulers. This was an old story: 'Have you murdered, and also inherited?' asked the prophet Elijah of King Ahab, who has confiscated his subject Naboth's estate after his wife engineers Naboth's death. ${ }^{23}$

An accounting remedy was developed by statute to supply the necessary tools for regulation of the sensitive socage guardian duties regarding the profits of the land. Here is the text of c. 17 of the 1267 Statute of Marlborough, reiterating very closely the language of the 1259 Provisions of Westminster c. 12:

It has also been provided that, if land which is held in socage is in the wardship of the kinsmen of the heir because the heir is under age, those guardians may not make waste or sale or any destruction of the inheritance but are to keep it safely for the benefit of the said heir, so that when he shall come of age, they are to answer him through a lawful accounting for the issues of the said inheritance with due allowance made to those guardians of their reasonable expenses. Nor may the said guardians give or sell the marriage of the said heir other than for the benefit of the same heir. ${ }^{24}$

The socage heir could take factual control of not possession of his land at age 14 , since he was then held able to hold a plough, and he could claim an account of all issues of the land during his minority

${ }^{22}$ Ranulf de Glanvill, Tractatus de Legibus et Consuetudinibus regni Anglie qui Glanvilla vocatur (The Treatise on the Laws and Customs of the Realm of England Commonly Called Glanvill) (c 1187-9) (GDG Hall (ed and trans), Nelson, London, 1965, reissued with notes by MT Clanchy, Oxford University Press, Oxford, 1993) VII, 11, pp 84-85. The same rule is repeated in Bracton, above $\mathrm{n} 18, \mathrm{ii}, 254$.

${ }^{23} 1$ Kings 21:19.

${ }^{24}$ Translation from Brand, above n 20, 477. 
from that moment, subject to deduction for the guardian's expenses in realizing the profits. There is much case law debating when the guardian could rightly claim that his expenses did swallow all the profits, requiring the court to 'tax' or measure the claimed expenses and prevent these becoming an exorbitant wage or profit-share.

This 'lawful accounting of issues' can be seen as a positive accounting measure to capture due profits, taking its place alongside the negative accounting measures of waste, used to combat losses or subtractions from the estate through prohibition, damages and confiscation of wardship. The seeds of this dual accounting are present in Magna Carta itself. Brand surmises that creation of enhanced protections against waste may have been the main goal of the 1259 legislators, and that the application of profit accounting for the issues of non-chivalrous tenures might have tacked on to the legislation as a minor extension, perhaps because the royal justiciar had recently been to Kent and had been lobbied by gavelkind tenants to give a remedy against pilfering guardians. There are hints that judges in the decades after the statute did in fact run waste and account remedies together, and in 1314 Bereford CJ cryptically states that account is the sole remedy for the socage ward on both the loss and gain sides. ${ }^{25}$ The idea floats downstream into the common law; in Fitzherbert's Natura Brevium of 1534 we have a laconic note that 'Waste lies not against the Guardian in Socage, but Account or Trespass'. ${ }^{26}$ Milsom concludes that waste was subsumed within account claims; the more potent remedy was to have the king remove the guardian and so direct the issues to the heir, with account yielding payments to fill in shortfalls in the guardian's receipts. ${ }^{27}$ In the same way courts today order account and compensation against a defaulting trustee to bring the trust assets back to their due state, and often displacing the trustee's title by assignment to the beneficiary or to fresh trustees. It is interesting that judges of the fourteenth century seem as unsure as those of the twenty-first whether damages for loss are a useful remedy for bringing missing profits into an abused estate. ${ }^{28} \mathrm{We}$ will continue with this juristic problem shortly, but first we may divert to consider the wider import of the rise of accountability controls in the earlier law.

\footnotetext{
${ }^{25}$ YB Mich 8 Edw 2, pl [16] (Common Pleas): "Note that it was ruled by BEREFORD C.J. that a writ of waste doth not lie against a guardian in socage, for the reason that he can be made accountable for waste by a writ of account"; Translation from William Craddock Bolland (ed), Year Books of Edward II, vol 18: 8 Edward II (1314) (Selden Society vol 37, London 1920) Note 47 p 219; also Seipp No $1314.117 \mathrm{ss}$.

${ }^{26}$ A Fitzherbert, La Novel Natura Brevium (Bertheleti, London, 1534), f 59E.

${ }^{27}$ SFC Milsom, Historical Foundations of the Common Law ( $2^{\text {nd }}$ ed, Butterworths, London, 1981) 240; see also The Legal Framework of English Feudalism (Cambridge University Press, Cambridge, 1976) 155-57.

${ }^{28} \mathrm{Cf} A / B$, text accompanying $\mathrm{nn} 7-11$, above.
} 


\section{ACCOUNT IN THE MEDIEVAL ECONOMY}

Actions of account were not invented by legislatures or courts to deal with socage guardians in the mid- thirteenth century. Some kind of accounting process is necessary whenever one person controls assets subject to the claims of another. An account at its simplest is a narrative of the control of an asset, detailing what has issued from the asset and what has been subtracted from it. In this simple sense, accounting is a pre-legal practice, and may be found in any civilization where settled farming and multi-handed production with an elaborated division of labour has taken hold, and also where jurisdictions involving rent-taking and taxation are instituted. Early accounting institutions may be found in the Ancient Near East, Antique Greece, and then the Roman and Islamic empires. The legal and calculative techniques of these latter empires provided models of accounting for medieval Europe; but the presence of demand for accounting summons techniques into existence, not the other way around. ${ }^{29}$

The Norman rulers of eleventh-century England made a notable if primitive contribution to accounting with the Domesday Book of 1086, requiring report of the productive and fiscal values of manors or organized farms at three dynamic points - pre-Conquest, the date of Conquest, and the date of the Domesday returns. The fiscal needs of the Angevin Crown in the twelfth century in turn required monetization of the King's claims against his tenants, and the new national system of account was described in the Dialogue of the Exchequer, probably written in 1177 by Richard FitzNagel who served as a treasurer to both Stephen and Henry II. FitzNagel relates how Henry II had to deal not only with a plague of disseisins in the wake of Stephen's anarchic reign, but also a jumble of tenurial claims to services up and down the feudal ladder that caused great discontent amongst the farmers. Meanwhile the king needed money to fuel his mobile military campaigns, more than the old claims to victuals levied against local manors. One solution was to institute a more elaborate national system of accounting for feudal dues, building on the inquests of feudal dues under Henry I involving accounting on a large chequered cloth by trusted barons that had been running from at least 1118 . This Exchequer system was adapted by Henry II to make the sheriffs liable to the Crown for all dues from the estates in his respective county, in monetized form. The Exchequer's distinctive accounting mechanisms used wooden tallies recording charges and discharges mandated by single-entry book keeping inscribed in pipe rolls. The system of charge and discharge of debt enshrined in tallies of wood broken into matching halves was crude but effective. The sheriffs would then have the responsibility of realizing

\footnotetext{
${ }^{29}$ Earlier modes of rent and tax extraction before the formation of national legal systems are analysed in C Wickham, Framing the Early Middle Ages: Europe and the Mediterranean, 400-800 (Oxford, Oxford University Press, 2005).
} 
the income flows from the manors of their respective counties, and could accordingly force an account on the tenants within their jurisdiction. Accounting at the Exchequer and county levels was perhaps the core technique of governance in the Anglo-Norman realm, as Milsom explains:

People were at first governed by the courts of county and hundred, those courts by the king. Government in the upper tier was largely a matter of accounting for what had become due to the king from the lower. Certain wrongs, for example, entailed a forfeiture to the king of the wrongdoer's goods; local institutions must therefore produce what was in effect a balancesheet of wrongs and goods, and would be penalised for any failure. ${ }^{30}$

Writs freely issued by the king's Chancery to enforce royal claims to an account were adapted, probably later in Henry II's reign, so as to enforce an account between actors lower down the feudal ladder. ${ }^{31}$ Due accounting in the manorial economy ensured a ready flow of fiscal return to the topmost layer, and in that sense public and private accounting enforced by royal actions formed a mutually supporting symbiosis. The Barons who met in the Exchequer Chamber to take sheriffs' accounts came to serve as an important royal court deciding all legal claims revolving around account. The Angevin accounting system based on the Exchequer is thus an important a foundation of the common law, perhaps of equal significance as the system of possessory assizes administered by the Court of Common Pleas that was also built up in Henry II's reign.

The tightening up of accounting systems from the later twelfth century came to embrace the lord's farm agents of steward, bailiff, and reeve, with local courts instituting controls modelled on the Exchequer and county practices. Moreover, the combination of war expenditure and rising population made this an era of price inflation where long leases at fixed rents led to a stagnation of returns flowing to the upper levels of the tenurial ladder. These factors - a desire to extract higher values from units of agrarian production, and the availability of new accounting techniques - combined to encourage a transformational shift in the techniques of manorial farming across the thirteenth century. This was "demesne" or direct or high farming, involving closer monitoring and disciplining of workforces through tighter control of work supervisors, and a turn to production for the market rather than autarkic production and trade in kind. New cadres of literate accounting professionals trained outside the church were summoned into existence by the new praxis. Thus fiscal demands from the top of the tenurial ladder spurred and reinforced capitalist micro-management lower down in the modes of agrarian production. The links between legalistic accounting and agrarian managerialism,

\footnotetext{
${ }^{30}$ Milsom, Historical Foundations, above n 27, 25-26.

${ }^{31}$ See references in $\mathrm{n} 12$, above. Brand, above n 20,65, dates the first "private" account writs around 1184-85.
} 
monetization, and transition from feudalism to capitalism, is one of the most important themes of economic and social historical analysis over the past century, transcending neoclassical and Marxist accounts of Western development. But this grand debate can only be noted and not pursued further within the bounds of this essay. ${ }^{32}$

Accountability could also be used as a weapon within the realm of high politics, as where the Crown sought to control magnates entrusted them with large military or trading budgets. Such claims for an account could be played out as political theatre, being enforced not according to regular legal procedures but rather by the motion of peers in great councils, backed by the threat of impeachment or trial for treason. Such a case provided a point of friction in the great struggle between Henry II and Thomas Becket prior to Becket's exile and eventual assassination. ${ }^{33}$ Becket had angered the king with his refusal to endorse the 1164 Constitutions of Clarendon curbing ecclesiastical privileges. Henry II at the Council of Northampton later that year brought demands that the Archbishop account for missing church and military revenues, amounting to $£ 30,000$ in silver; it seems that Becket as Chancellor had been granted great funds to levy war in France and besiege some castles, but he held back from battle and kept back the funds also. Henry backed his demand for account and restitution with a threatened treason charge. Becket replied by insisting that his appointment as archbishop had taken him out of secular jurisdictions and amounted to a cancellation of all possible debt claims against him:

My lord the king knows that I have often enough rendered accounts for everything which he now claims from me before I was elected archbishop of Canterbury, and upon my election [the king, barons and justiciar] have quitclaimed me before God and Holy Church for all

\footnotetext{
${ }^{32}$ For a sample of significant work, see FW Maitland and WP Baildon, eds, The Court Baron: Being Precedents for Use in Seignorial and other Local Courts, Together with Select Pleas from the Bishop of Ely's Court of Littleport (Selden Society vol 4, London, 1891); FW Maitland, 'A Conveyancer in the Thirteenth Century' (1891) 25 Law Quarterly Review 63; P Vinogradoff, The Growth of the Manor (Macmillan, London, 1905); N Denholm-Young, Seignorial Administration in England (Cass, London, 1937); Plucknett, above n 12; Stoljar, above $n$ 12; D Oschinsky, Walter of Henley and other Treatises on Estate Management and Accounting (Clarendon Press, Oxford, 1971); PDA Harvey, 'The Pipe Rolls and the Adoption of Demesne Farming in England' (1974) 27 Economic History Review 345; J Bolton, The Medieval English Economy 1150-1500 (2 ${ }^{\text {nd }}$ edn, JM Dent, London, 1985) chs 2-4; 'The Manorial Reeve in Twelfth Century England', in R Evans (ed), Lordship and Learning: Studies in Memory of Trevor Aston (Boydell, Woodbridge, 2004) 125-38; PA Brand, 'Stewards, Bailiffs, and the Emerging Legal Profession', in Evans, loc cit, 138-53, and above n 20; C Noke, 'Agency and the Excessus Balance in Manorial Accounts' (1991, reprinted with 'Postscript', in RH Parker and BS Yamey, Accounting History (Oxford University Press, Oxford, 1994); Z Razi and R Smith, 'The Origins of the English Manorial Court Rolls as a Written Record: A Puzzle' (1996); J Sabapathy, Officers and Accountability in Medieval England 1170-1300 (Oxford University Press, Oxford, 2014); Licht, above $\mathrm{n} 12$.

33 R van Caenegem, ed, English Lawsuits from William I to Richard I: Vol II (Selden Society vol 107, London, 1991) Case 421, 433-57.
} 
receipts and computations and all secular exactions on behalf of the lord king .... I was elected

... free and absolved and therefore I refuse to plead on this any more. ${ }^{34}$

The Council ordered his arrest and imprisonment to compel account, but Becket told the barons who came to deliver the judgment that they would be placed under anathema if they dared pronounce the judgment. Rather than submit to account and so compromise his wide claims of ecclesiastical immunity for himself and for all churchmen, Becket fled to France. Power to claim an account had here become a struggle over sovereignty and immunity. Here too lay seeds of the future, for impeachment for mishandling of public accounts was a process that would be followed many times in later English history, eventually leading to new equitable controls over fiduciaries in the early eighteenth century. ${ }^{35}$ But this transformation of account represents a separate historical stream, distinct from the feudal and manorial controls enshrined in Magna Carta. The major development of accountability in the time of Magna Carta concentrated on a different problem: how to control waste.

\section{WASTE ACTIONS: THIRTEENTH-CENTURY ELABORATION}

If account and waste were entwined actions regulating feudal guardianship at the time of Magna Carta, then we need to know how waste operated in the early common law to complete our understanding of accountability. Bracton's De Legibus can be taken as a useful guide to the contemporary meaning and extent of waste, as it was written down within a decade or so after 1215. Bracton's definition indeed turns out to be a close paraphrase of the 1215 texts:

So long as the guardian has the wardship of the land let him maintain the houses, parks, game preserves, ponds, mills and all things belonging to that land out of the issues of the same, and restore to the heir, when he comes to full age, all his land stocked with plough teams and all other things, at the least no less well stocked than he found it. He shall take nothing from the heir's land while he is under age except rightful issues, rightful customs and rightful services, and this without destruction and waste of men or things. If he commits such acts, whether a prohibition has issued or not he shall lose the wardship and make good the damage, and because of the wrongdoing let the land be handed over to [two] lawful and honest men, or the nearer kinsmen, as will be explained below [in the portion] on actions. If the king, for whatever reason, has the wardship of land and has transferred it to the sheriff or another,

\footnotetext{
34 Ibid, 435.

$35 \mathrm{~J}$ Getzler, Rumford Market and the Genesis of Fiduciary Obligations', in A Burrows and A Rodger, eds, Mapping the Law: Essays in Honour of Peter Birks (Oxford University Press, Oxford, 2006) 577598.
} 
who is to answer for the issues to the king, and such person commits destruction or waste, let the king take the wardship and amends from him and let the land be entrusted to two lawful and discreet men of that fee who shall answer for the issues to the lord king or to him to whom the king has assigned those issues. If the king has given or sold the wardship to another who commits destruction or waste, let him lose the wardship and the land be entrusted to the two, as was said above. ${ }^{36}$

Waste here means the dilapidation of the estate so that the capital value going to the heir or remainderman is diminished. This can result from the prior holder taking out too much profit; putting in too little investment; failing to take protective measures, whether knowingly or negligently; or even wilfully destroying the land or its attachments such as houses, timber and emblements, known as "degradation" denoting a particularly atrocious form of waste. "Exile" was a separate heading of waste involving severance of bondsmen, that is villeins, from the land. ${ }^{37}$ Through waste land capital is extracted, investment income diverted, or value diminished or lost outright. Bracton distinguishes two main categories of parties who capable of committing waste, a guardian who held the land of a ward, or a widow holding in dower. To that list was added in due course a lessee, from at least the Provisions of Westminster of 1259 , and then the life tenant, from the Statute of Gloucester 1278, though according to Maitland, the life tenant was already bound in Bracton's time. ${ }^{38}$ The lease case was interesting because, as Hyams points out, there was a great concern that villeins or unfree serfs attached to the land should not be released by the termor without authority, as their bonded presence was part of the long-term reversionary value of the land. ${ }^{39}$ This policy is evoked in the Statute of Marlborough 1267 c. 23 (incorporating Provisions of Westminster 1259 c. 20):

Also lessees during the period of their leases are not to make waste, sale or exile in the woods, houses, men or of anything else belonging to the tenements which they have on lease, unless they have a specific concession in the writing of their agreement mentioning that they may do these things. And if they do this and are convicted of doing so they are to refund the damages in full and to be heavily punished by amercement. [emphasis added] ${ }^{40}$

So a range of parties were expected to pass on the land and its appurtenances (including its workforce) intact to a designated heir or remainderman or reversioner when their office, estate or term came to

\footnotetext{
${ }^{36}$ Bracton, above $\mathrm{n} 18, \mathrm{ii}, 252-53$.

${ }^{37}$ Fleta, Seu Commentarius Iuris Anglicani (Fleta, A Commentary on the Laws of England) (c 1290) (HG Richardson and GO Sayles (ed and trans), Selden Society vol 72, London, 1955) ii, Bk I c 12, p 25.

${ }^{38}$ See Pollock and Maitland, above n 3, ii, 9; Brand, above n 20, 63-64, 345-47.

${ }^{39}$ PR Hyams, Kings, Lords, and Peasants in Medieval England: Common Law Villeinage in the Twelfth and Thirteenth Centuries (Oxford University Press, Oxford, 1980) 25-27.

${ }^{40}$ Translation from Brand, above n 20, 479.
} 
an end; we may contrast the ordinary holder of a fee who was entitled to consume his own estate to the disherison of his heirs, since those heirs were not relevantly vested with seisin until his death.

The types of conduct establishing a cause of action for waste were well defined, and set out particularly clearly in Bracton's discussion of control of a widow's dower. ${ }^{41}$ It was expected that the holder of the estate or wardship could take reasonable income, described as issues or estovers, from the land, but if that measure was exceeded the land (in the case of a widow) would be put into administration under the control of others and restitution ordered, or (in the case of a guardian) the wardship would be confiscated and re-assigned at the mercy of the king, and amercements to the king exacted. ${ }^{42}$ Coke in his exegesis of cc. 4 and 5 of Magna Carta really makes this aspect the centrepiece of the story, for it fits in to his wider vision of the common law as the embodiment of practical reason. He writes that the 'rents and profits issuing out or coming of the lands...must be taken by the guardian in reasonable manner, and therefore to exitus, rationabiles is added, for that nothing that is unreasonable is allowed by law'. ${ }^{43}$

\section{THE UNION OF ACCOUNT AND WASTE, AND THE GEOMETRY OF MANAGERIAL RELATIONS}

Brand has shown how accounting actions grew in scope and frequency after the legislation of the 1250 s and 1260s, partly to regulate the internal workings of manors by applying controls to the managerial staff of stewards, bailiffs and reeves; partly to control guardians themselves in their relationship with wards, and make the guardian responsible for the managerial staff who in practice ran the estates held of wards. For example the Statute of Marlborough, building on the Provisions of Westminster of $1259 \& 1263 / 4$ also and 1267 , extends the reach of the petty assizes such as novel disseisin making stewards answerable in court as responsible agents or representatives of their lords. Statute simultaneously improved the control of lords over their bailiffs, for example allowing lords to apply not only distress but bodily attachment and even outlawry to absconding bailiffs in order to ensure a due account was made and satisfaction of outstanding debts given. By the late thirteenth century the central courts are increasingly intervening under statutory powers to order accounts to be taken and debts to be paid, applying a common-law overlay to local jurisdictions.

\footnotetext{
${ }^{41}$ Bracton, above $\mathrm{n} 18, \mathrm{iii}, 405-410$.

${ }^{42}$ Bracton, above $\mathrm{n} 18, \mathrm{iii}, 410-411$.

${ }^{43}$ Sir Edward Coke, The Second Part of the Institutes of the Laws of England: Containing the Exposition of Many Ancient and other Statutes (London, 1642, reprinted W Clarke, London, 1817) i, "Magna Charta Cap. 4": 12(2).
} 
We can see a multiplicity of complex correlative legal relations emerging over time as actions such as waste and account are elaborated by statutory and curial extension, and juxtaposed with familiar writs of dissessin and nuisance. These may be listed as follows:

1 A ward can sue his guardian not only for waste but for disseisin. A guardian who assigned land to the disherison of the ward might have the wardship removed to the next non-inheriting relative to stand as guardian (Statute of Westminster 1275 c. 48), adding a further remedy to the possessory assizes.

2 A guardian can sue for disseisin or waste on behalf of a ward against a third party where the ward is prevented from suing. Thus the Statute of Westminster II (1285) c.15:

In every case where minors under age may sue it is conceded that, if such minors are removed and so they are unable to sue in person, their next of kin are to be admitted to sue on their behalf.

3 A ward can sue his guardian's assignee, for example a lessee, as the ward's interest is attached to and follows the land; it is not a privy claim founded on the ward's close kinship to the guardian relative. In such a case the lessee is enriched by the issues and so should pay them over rather than allow the ward to be impoverished. ${ }^{44}$

4 A ward can sue to correct waste or disseisin caused by a lord's bailiff's or steward's acts. Land can be attached and the estate recovered by suing a steward in place of the lord if the lord cannot be brought to court. In Glanvill a distinction is drawn between a 'responsalis', an attorney or representative who stands in for the lord in court and can bind the lord, and the 'balliu' or 'senescal' (manorial bailiff or steward) who is empowered to dispose of land and goods for the lord but can only serve as attorney who can plead and bind the lord if specially appointed as such. ${ }^{45}$

$5 \mathrm{~A}$ lord can sue his steward, bailiff, or reeve to bring him to account for the management of his land, using a panoply of enforcement devices to being the agent to heel. ${ }^{46}$ These accounting practices are codified in the 1285 Statute of Westminster II, c. 11, discussed below.

\footnotetext{
${ }^{44}$ YB Mich 2 Edw 2, pl [14]; FW Maitland, ed, Year Books of Edward II, Vol 1: 1 \& 2 Edward II (13071309) (Selden Society vol 17, London 1903) 107-110; Seipp No 1309.051ss.

${ }^{45}$ Glanvill, above $\mathrm{n} 22, \mathrm{XI}: 1-2$, at 131-34.

${ }^{46}$ Licht, above $\mathrm{n} 12$; Watson, above $\mathrm{n} 12,78-83$.
} 
6 Representative bailiffs could in turn sue to enforce account against tenants and servants on behalf of the lord. Plucknett in his seminal 1953 Creighton Lecture on 'The Mediaeval Bailiff' notes that such men could not only legally represent the lord in litigation but initiate litigation in the court baron on behalf of the lord, and thus apply governmental discipline to the population of the manor. ${ }^{47} \mathrm{~A}$ practical union of managerial and prosecutory powers is evidenced in Maitland's compendium of bailiffs' and stewards' records and manuals entitled The Court Baron from $1891,{ }^{48}$ and this suggests that Glanvill's distinction of bailiffs and attorneys blurred in practice.

7 The concentration of power to enforce an account over the workforce could be oppressive, and was itself subjected to forensic controls such as c. 38 of Magna Carta, in effect a duty of meta-account, or duty to provide information as a precondition for exercise of power to hold others to account:

No bailiff, for the future, shall put any man to his law, upon his own simple affirmation, without credible witnesses produced for that purpose.

The problem here was an endemic one of information imbalance in the accounting process. The flow of inputs and outputs in any economic relationship might not always produce probative evidence beyond the parties' own witness, and this could lead to unequal forensic contests where one or the other side was put to wager of law to prove or deny that a receipt or disbursement had occurred. It was particularly difficult to prove a negative. Complaints about procedural unfairness on the part of baronial bailiffs and royally appointed sheriffs when enforcing accounts show up in local politics across the thirteenth century. ${ }^{49}$ The problem is mirrored in the doctrinal history; the later development of account revolved around finding alternative trespassory writs of action and equitable suits that avoided the evidential pitfalls of compurgation and wager of law. ${ }^{50}$

8 The 1285 Statute of Westminster II, c. 11, known as the Accountants Act, extends the legal accounting process to "all manner of receivers", thus making the leap from manorial bailiffs outwards to agents and fiduciaries generally:

Concerning servants, bailiffs, chamberlains, and all manner of receivers, which are bound to yield account, it is agreed and ordained, that when the masters of such servants do assign auditors to take their account, and they be found in arrears upon the account, all things allowed which ought to be allowed, their bodies shall be arrested, and by the testimony of the

\footnotetext{
${ }^{47}$ Plucknett, above $\mathrm{n} 12,11-15$.

${ }^{48}$ Above n 32; and see Brand, 'Stewards, Bailiffs, and the Emerging Legal Profession', above n 32.

${ }^{49}$ JR Maddicott, 'Magna Carta and the Local Community' (1984) 102 Past \& Present 25.

${ }^{50}$ Watson, above n 12, 39-76.
} 
auditors of the same account, shall be sent or delivered unto the next jail of the King's in those parts.

The 1285 statute describes an elaborate system of audit for taking accounts, the possible offsets and defences, and then the remedies and enforcement mechanisms including attachment of the person to force an account. The statutory codification led to new equitable procedures developing in the common law courts whereby any person controlling assets or receiving payments on some condition to hold to the use or benefit of another could be subject to accounting remedies. The statute is thus a main conduit by which the accounting process moved from feudal relations and manorial controls outward to the commercial economy. The great expansion of legal accountability first codified in Magna Carta in 1215 thus burst its feudal bounds just seventy years later. The old writs of waste and account by the fourteenth century were developing into a general law of management. ${ }^{51}$

\section{CONCLUSIONS}

And now to summarise the strands of this history and suggest how they might bear on our present law. Waste and account actions as the negative and positive sides of managerial control cannot entirely be merged, but they are intimately related in the first centuries of English law. Waste actions are wrong-based claims sounding in damages, but with droitural and proprietary characteristics, regulating tenurial and guardianship duties and thus preventing abuse of feudal relations. To give an account is rather different than to compensate for waste. It is to tell the story of one's management or stewardship of resources, whether to one's lord or ward, heir or remainderman, or (later) to one's commercial principal, joint tenant or partner, or trust beneficiary. One may be called to account in court, or in an extra-judicial process be required to narrate and justify one's management to an auditor appointed to hear the account and make investigation in order to ensure that due performance is given. A process of account is internal to any managerial relationship and can happen normally without court intervention. A court may become involved in order to overcome recalcitrance in providing information (by imprisonment, by inquest, or other mesne process), or to order the correcting of any default. Whether ordered in court or administered without, account was intrinsic to

\footnotetext{
${ }^{51}$ See generally references in $\mathrm{n} 32$, above, and also PA Brand, 'The Equity of the Common Law Courts', in E Koops and WJ Zwalve, eds, Law and Equity: Approaches in Roman Law and Common Law (BrillNijhoff, Leiden, 2013) 39-53; PA Brand, 'Merchants and their use of the action of account in thirteenth and early fourteenth century England', in M Allen and M Davies, eds, Medieval Merchants and Money: Essays in Honour of James L Bolton (Institute of Historical Research, School of Advanced Study, University of London, 2016). Accounting for executors may have taken a different juristic path: see $\mathrm{N}$ Perram, 'The operations and present operation of the action in devastavit' [2012] Society of Trust and Estate Practitioners / Federal Judicial Scholarship 23.
} 
management, and was not a curial construction, a displacement of self-help, in the way that writs of waste or dissesin or trespass were.

The historical action of account, being the narration and enforcement of due management, inevitably presents a positive and a negative dimension. On the positive side due earnings are expected. If one has failed to earn or collect requisite profits or diverted profits generated by assets to one's own pocket or that of another, the account is surcharged for the missing assets; and on the negative side, if one has paid away assets or allowed the assets to decline in value in breach of duty then you must restore the estate to the level of assets before the wrongful decline occurred. In both cases one may be required by a court to pay an entire, non-divisible debt, a liquidated sum, being a personal duty to top up the estate or fund (that is, the collection of assets, from fundus, farm) so that its value is brought or restored to where it should have been. Waste, by contrast, was pre-eminently a doctrine to discipline a person who controlled the estate of another - pre-eminently guardians, but also widows, lessees, remaindermen. For a chivalrous tenure the guardian could keep the profits, but if the profittaking was so great that capital was leached, or if non-investment led to capital degradation, then the withholding of issues by the guardian would be corrected. Waste was subsumed within account for the socage guardian, who had to restore the estate to the ward fully stocked with issues; subtracted profits went into the account. Thus waste merged into account measures; the actions marched together, repressing loss and enforcing gain at one and the same time. Such a dual metric was essential to maintain the health of managerial relations.

Account typically applied to control a steward, bailiff or reeve charged with management at strategic or ground level of a farm or estate, that is, a principal could reach down to control an inferior entrusted with asset management. But account could reach upwards as well, as where a socage guardian is made accountable to the heir preceding majority. With the 1285 Accountants Act, the remedy is extended beyond bailiffs and guardians in the context of estates to embrace all possible receiver relations, and becomes the kernel for a general theory of fiduciaries.

The practical significance of chapters 4 and 5 of Magna Carta ebbed away as the law developed new procedures after 1285 . The whole area was transformed by the absorption of account actions into new procedures, first in King's Bench trespass counts of assumpsit, and then in Chancery suits. This supersession of account within new forms of action should not conceal from us to the importance of the earlier statutes in providing the juristic foundations. 
We do find the old law of account and waste evoked in Magna Carta cropping up occasionally in later cases, but usually to show its desuetude. For example in 1598 we find counsel arguing that the subversion of a warren by a lessee was waste under Magna Carta c. 5, as the warren was a liberty of the land caught by the connotation of 'issues'. The argument went nowhere:

For the Court held it was not waste to destroy cony-boroughs, for wast will not lye for conies, because a man hath not inheritance in them, and a man can have no property in them but only possession, and although by a speciall law, keepers are to preserve the land they keep, in the same plight they found it, yet this does not bind every lessee of land. ${ }^{252}$

But even if actions derived from Magna Carta no longer had purchase, their importance was not lost on lawyers of that time. Sir Edward Coke was certainly aware of the history. He concludes his elaborate discussion of accountability under Magna Carta c. 5 in the Second Institutes by recounting the object lesson of Ranulph, Lord Chancellor and then Bishop of Durham under William Rufus, who used his offices to engage in simony or exploitation of church wealth and livings on a vast scale. Henry I on his accession sought to apply a remedy in account to deal with this corrupt official, without being seen to trenching on the privileges of the church. The new king laid his ground carefully by making a charter at his coronation promising to protect the church, and he used this royal power to intervene in the Ranulph case most vigorously. Coke's recounts the story thus:

Ranulph ... was a factor for the king (William Rufus) in making merchandize of church livings, in as much, as when any archbishopricke, bishopricke, or monastery became void, first he perswaded the king to keepe them voide for a long time, and converted the profits thereof sometime by letting, and sometime by sale of the same, whereby the temporalities were exceedingly wasted, and destroyed.... This Ranulph, for serving the kings turnes, was advanced, first, to be the kings chancellour, and after to be bishop of Duresme, who after his advancement to so high dignities, made them servants to his sacrilegious and simoniacall designes. King Henry the first seeing this mischief ... committed the said Ranulph ... to prison for his intolerable misdeeds, and injuries to the church, where he lived without love, and died without pity, saving of those, that thought it a pity, he lived so long. ${ }^{53}$

Ranulph's imprisonment is presented as a punishment for the waste done to church estates and offices; we are not told explicitly whether the sanction resulted in an account and disgorgement of Ranulph's ill-gotten gains. In the thirteenth-century legislation, coercion of the person of accountable

\footnotetext{
${ }^{52}$ Moyle v Mayle (1598) Owen 66, 67; 74 ER 905 (KB).

${ }^{53}$ Coke, above n 43, 15.
} 
parties by imprisonment was in fact heightened as a mesne remedy to enforce compliance. ${ }^{54}$ The danger in Coke's presentation of this stringent remedy is to lose sight of the deeper ambitions of the law of account - not to punish wrongdoing, not to force the payment of damages for inflicted loss, but rather to hold powerful managers to a due performance, doing right rather than correcting wrong. If Coke could lose that perspective and focus on loss rather than performance, then perhaps we can better understand why the Supreme Court in 2015 decided AIB $v$ Redler as it did. But these few precedents do not mandate that the original ambitions of the old actions of account should now be abandoned; there is plenty of historical evidence to argue the other side.

${ }^{54}$ Provisions of Westminster 1259 c. 19; Statute of Marlborough 1267 c.23; Statute of Westminster II 1285 c. 11; discussed Brand, above n 20, 65-66. 